\title{
Nilai-Nilai Moral Islam dan Keseteraan Gender dalam Novel Eliana Karya Tere Liye
}

\author{
Ida Novianti ${ }^{1}$, Wahyu Budiantoro ${ }^{2}$ \\ ${ }^{1}$ Universitas Islam Negeri (UIN) Prof. K.H. Saifuddin Zuhri Purwokerto - Indonesia \\ ${ }^{2}$ Universitas Islam Negeri (UIN) Prof. K.H. Saifuddin Zuhri Purwokerto - Indonesia \\ Email Penulis: ${ }^{1}$ idanovianti@iainpurwokerto.ac.id, ${ }^{2}$ budiantoro.wahyu@yahoo.co.id
}

Article Information

$\begin{array}{llll}\text { Submitted } & : 2021-05-22 & \text { Revision } & : 2021-11-10 \\ \text { Reviewed } & : 2021-10-11 & \text { Published } & : 2021-11-30\end{array}$

Abstract: Eliana's novel emphasizes Islamic moral values and gender equality, where these values are inserted through dialogues and activities carried out by the characters. Starting from the first chapter, Eliana has been depicted as a girl who has an awareness that society treats boys and girls differently solely based on their sex. So she tried to show that her abilities were commensurate with boys deserving of awards. This characteristic is considered strange and unusual for the society in the village. The moral values of Islam contained in Eliana's novels include tauhid, honesty, courage, cooperation, qana'ah, discipline, love, birrul walidain, responsibility, keeping promises, harmony, love of nature, forgiveness and earnest. The value of gender equality in Eliana's novel is seen from three things, namely the views of male and female figures and vice versa, the image of male and female leaders, and the roles of male and female leaders.

Keyword: Morality, Islam, Gender, Eliana's Novel

Abstrak: Novel Eliana mengedepankan nilai-nilai moral Islam dan kesetaraan gender,
di mana nilai-nilai ini disisipkan melalui dialog-dialog maupun aktifitas yang dilakukan
oleh para tokohnya. Mulai dari bab pertama sudah tergambar sosok Eliana sebagai
anak perempuan yang memiliki kesadaran bahwa masyarakat memperlakukan anak
laki-laki dan perempuan secara berbeda semata-mata berdasarkan jenis kelaminnya.
Sehingga dia berusaha untuk menunjukkan kemampuan yang dimilikinya sepadan
dengan anak laki-laki layak untuk mendapatkan penghargaan. Sifatnya ini dianggap
aneh dan tidak lazim untuk ukuran kehidupan di kampungnya. Nilai-nilai moral Islam 
yang terdapat dalam novel Eliana ini diantaranya adalah tauhid, kejujuran, keberanian, kerja sama, qana'ah, disiplin, cinta kasih, birrul walidain, tanggung jawab, menepati janji, kerukunan, cinta alam, memaafkan dan bersungguh-sungguh. Nilai kesetaraan gender dalam novel Eliana dilihat dari tiga hal yaitu pandangan tokoh laki-laki terhadap perempuan dan sebaliknya, citra tokoh laki-laki dan perempuan, serta peran tokoh lakilaki dan perempuan.

Kata Kunci: Moral, Islam, Gender, Novel Eliana

\section{Pendahuluan}

Menulis buku bisa dikatagorikan sebagai salah satu wujud pendidikan masyarakat. Dengan menulis yang baik, artinya turut menyebarluaskan ilmu pengetahuan maupun nilai-nilai moral yang baik sehingga diketahui oleh masyarakat. Buku terbagi dalam beberapa segmen, yaitu buku ilmiah, buku popular dan buku fiksi. Novel merupakan katagori buku fiksi yang disukai oleh banyak kalangan karena dianggap sebagai bacaan ringan, menghibur dan menyenangkan.

Secara umum novel terdiri dari beberapa ragam genre, Anne Ahira membagi novel ke dalam lima genre. Pertama yaitu novel romatis,yang bercerita tentang kisah percintaan dan kasih sayang. Sepanjang cerita akan disuguhi konflik percintaan yang dipadukan dengan romantisme. Kedua, novel horror yang memiliki cerita menegangkan. Biasanya terkaitan tentang dunia mistis dan gaib. Ketiga adalah novel misteri, jenis novel ini lebih rumit karena biasanya berisi tentang teka teki sebuah peristiwa yang harus dipecahkan. Membaca novel misteri membuat pembaca merasa penasaran sehingga tidak akan berhenti sampai menemukan jawaban dari teka teki tersebut. Keempat, novel komedi.

Sebagaimana namanya, novel ini bersifat menghibur, berisi tentang kejadiankejadian lucu yang membuat pembacanya tertawa. Dan kelima adalah novel inspiratif. Novel inspiratif adalah jenis novel yang ceritanya mampu menginspirasi banyak orang. Umumnya novel ini sarat akan pesan moral dan hikmah tertentu sehingga pembaca merasa mendapat dorongan dan motivasi untuk melakukan suatu kebaikan (anneahira.com).

Novel diterbitkan dengan beberapa alasan, pertama harapan agar novel tersebut disenangi masyarakat sehingga hasil penjualannya memberikan keuntungan secara financial. Kedua, untuk menyebarkan nilai-nilai yang ada dalam novel sehingga diikuti oleh masyarakat luas. Nilai-nilai yang baik akan memberi pelajaran yang 
baik dan akan memberikan keuntungan yang baik tidak hanya di dunia, tetapi juga di akherat sebagi bagian dari amal jariyah. Ketiga, sebagai bahan uji coba dan proyek idealisme.

Remaja merupakan sasaran terbesar dari pemasaran novel, sehingga memasukkan nilai-nilai moral melalui novel merupakan hal yang efektif. Pada saat membaca novel, remaja tidak merasa digurui atau dinasihati. Mereka merasa sedang melakukan hobi yang disukainya, yaitu membaca novel.

Salah satu novel yang digemari remaja saat ini adalah karya Tere Liye. Novelnovel karya Tere Liye berkisah seputar hubungan keluarga, persaudaraan, kasih sayang, persahabatan, motivasi, dan tentu saja hubungan laki-laki dan perempuan. Dengan bahasa yang lugas, berlatar kehidupan sehari-hari dan problematika yang dialami oleh pembacanya, novel Tere Liye bisa diterima oleh segala kalangan. Segmen pembaca novel karya Tere Liye berjenjang mulai dari anak-anak SD, remaja SMP dan SMA, mahasiswa, sampai ibu rumah tangga dan pekerja.

Sebagai sebuah karya sastra dan fiksi, novel memiliki struktur yang dibuat sedemikian rupa sehingga menyerupai fakta, yaitu adanya alur cerita, tema, tokoh, latar peristiwa, sudut pandang dan gaya. Novel memiliki genre tertentu, misalnya novel horor, novel popular, novel drama, novel islami dan sebagainya. Novel karya Tere Liye dikatagorikan sebagai novel popular dan drama. Meski tidak bergenre novel islami, novel-novel Tere Liye mengandung nilai-nilai universal yang sesuai dengan nilai-nilai keislaman. Justru di sinilah pentingnya sebuah bacaan, ia tidak membatasi dirinya dengan sebutan bacaan/novel islami. Seringkali ketika sebuah karya digolongkan dalam genre tertentu hal itu justru membatasi segmen pembaca.

Cerpen atau novel dalam sastra dapat berfungsi sebagai kritik atas ketimpangan sosial, membangun kesadaran sosial, dan transformasi nilai-nilai kehidupan. Oleh karena itu penggambaran peristiwa, tokoh dan settingnya sebisa mungkin dibuat mendekati fakta-fakta yang ada. Seorang tokoh dalam cerpen bukan hanya mewakili gambaran seseorang tetapi juga mewakili sebuah golongan. Tokoh itu lantas menjadi lambang, yakni lambang tertentu dalam masyarakat (Sumarjo, 2004).

Novel Tere Liye yang berjudul Eliana merupakan satu dari tetralogi Serial Anak-Anak Mamak yang terdiri dari empat judul yaitu Eliana, Pukat, Burlian dan Amelia. Eliana merupakan buku pertama dari keempat tetralogi tersebut yang mengisahkan tentang kehidupan keluarga Pak Syahdan yang sederhana dan tinggal di sebuah kampung yang masih alami, berbatasan dengan hutan, sungai, sawah dan kebun. 
Tokoh Eliana merupakan lambang anak perempuan yang pemberani. Dia sulung dari empat bersaudara yang meski hidup sederhana tetapi dibesarkan dengan penuh kasih sayang dan saling menghormati dalam keluarga. Secara umum, keluarga Pak Syahdan dan penduduk lainnya di desa mereka hidup dalam ekonomi yang pas-pasan, fasilitas pendidikan seadanya, sarana pra sarana yang jauh dari memadai. Mereka membuka ladang-ladang di hutan yang cukup untuk menghidupi keluarga mereka.

Eliana berani menghadapi tantangan hidup yang menghadangnya, selagi ia meyakini bahwa ia berada pada posisi yang benar. Ia melakukan perlawanan terhadap ketidakadilan yang menimpa dirinya, keluarganya, bahkan masyarakatnya. Sebagai seorang perempuan tidak mudah bagi Eliana untuk melakukan perlawanan, banyak tantangan yang harus dihadapinya, bahkan yang berasal dari orang terdekatnya. Namun dengan kegigihan, usaha dan kerja keras Eliana mampu menunjukkan bahwa meski seorang perempuan ia bisa melakukan kebaikan, mampu berprestasi dan berani melawan ketidakadilan yang menimpanya.

Meskipun Eliana bukan novel bergenre Islami, tetapi banyak muatan nilainilai moral Islami yang secara eksplisit dimasukkan dalam novel ini. Jenis-jenis akhlak mulia dalam Islam antara lain adalah: berani dalam hal kebaikan, adil, bijaksana, mendahulukan kepentingan orang lain dibanding kepentingan pribadi, pemurah, ikhlas, bertobat jika melakukan kesalahan, jujur dan benar, tenang dalam menghadapi masalah, tidak berkeluh kesah, amanah, sabar, pemaaf, kasih sayang dan belas kasih, lapang hati, iffah (menjaga diri), khaya' (pemalu), tawadhu' (rendah hati), mengutamakan perdamaian, zuhud, ridla atas ketetapan Allah, setia, syukur, musyawarah, tawakal, dinamis, ramah, peduli, menghormati, rela berkorban.

Dengan kata lain banyak nilai moral Islam yang direpresentasikan dalam novel tersebut. Moralitas diartikan sebagai sifat dasar dari pribadi (orang) atau keseluruhan asas dan nilai yang dipahami seseorang, sehingga setiap orang berperilaku terpuji (Bertens, 2002). Moral kerap disamakan dengan etika. Secara etomologi, etika berangkar dari kata "ethos" yang artinya watak (Tim Penyusun, 1995). Sementara, Wahab (2020) mengartikan etika sebagai penuntun dalam bersikap dan bertindak dalam kehidupan.

Dalam Islam, etika/ moralitas disebut sebagai al-adab. Intinya sama, yakni berubungan dengan budi pekerti dan nilai yang baik . Namun, al-Ghazali membedakan antara etika/ moral/ al-adab dengan al-akhlaq. Al-adab merupakan tata krama baik dan buruk. Sedangkan, al-akhlaq adalah watak kejiwaan yang 
paling dalam, yang juga berkaitan dengan perbuatan dan pemikiran (Al-Jaziri, n.d.). Dengan demikiran, moralitas Islam merupakan perwatakan, sikap, perilaku yang baik, yang berdasarkan nilai-nilai luhur agama Islam, terutama al-Qur'an dan Hadits. Pada novel Eliana, unsur moralitas Islam juga cukup tergambarkan, misalnya: hubungan manusia dengan Tuhan, hubungan manusia dengan sesama, manusia dengan lingkungan sosial, sikap peduli, tanggung jawab dan disiplin (Pratiwi, 2013).

Selain itu, novel ini secara tidak langsung mengedepankan kesetaraan gender, di mana nilai-nilai ini disisipkan melalui dialog-dialog maupun aktifitas yang dilakukan oleh para tokohnya. Mulai dari bab pertama sudah tergambar sosok Eliana sebagai anak perempuan yang memiliki kesadaran bahwa masyarakat memperlakukan anak laki-laki dan perempuan secara berbeda semata-mata berdasarkan jenis kelaminnya. Sehingga dia berusaha untuk menunjukkan kemampuan yang dimilikinya sepadan dengan anak laki-laki layak untuk mendapatkan penghargaan. Sifatnya ini dianggap aneh dan tidak lazim untuk ukuran kehidupan di kampungnya.

Gender merupakan sistem pengaturan dan transformasi biologis menjadi perilaku manusia. Lanjut Barker (2000), gender juga sebuah konstruksi budaya yang sifatnya terbuka pada perubahan. Artinya, gender menjadi sistem biologis dan sosial yang dinamis. Memposisikan gender dengan produktif bisa meminimalisir diskriminasi gender. Gender juga berkaitan dengan representasi. Aspek kultural lebih dikedepankan daripada alamiah (Juditha, 2015). Meskipun pemikiran dikotomik terhadap isu gender tetap ada. Representasi gender biasanya diakomodir oleh karya sastra. Oleh sebab itu, dalam dunia sastra terhadap kritik sastra feminis yang fokus kajianya berkisar pada isu gender dan perempuan (Muzzakka, 2017).

Isu gender dan Islam dalam novel sudah cukup jamak dibahas. Dalam konteks gender misalnya, penelitian Mufidah Ch dkk. (2021) tentang "Analisis Gender Dalam Novel “Aku Lupa Bahwa Aku Perempuan” Perspektif Emansispasi Perempuan Qasim Amin" menunjukan bahwa gender masih diposisikan secara stereotipe, apalagi dalam konteks kenegaraan. Artinya, masih ada bias gender. Persoalan stereotipe dalam diskursus gender juga dinyatakan dalam penelitian Intan (2020). Novel Malik dan Elsa karya Boy Candra menjadi subjek. Hasil penelitian itu menunjukan bahwa satu-satunya kesetaraan gender yang disepakati dalam novel tersebut ialah perjuangan seorang laki-laki mendapatkan perempuan yang dicintainya.

Dalam novel Gadis Pantai karya Pramoedya Ananta Toer, isu gender masih sangat dikotomik. Temuan itu disampaikan Saputro (2017). Dia mengatakan bahwa 
dikotomi tersebut dikarenakan letak geografis, yang berujung pada stereotip gender. Perempuan priyayi dianggap terhormat, sedangkan perempuan desa identik dengan kemiskinan dan kebodohan. Stereotip terhadap gender umumnya diakibatan oleh kesalahpahaman terhadap konstruksi budaya dan agama, sehingga bias gender kerap terjadi secara masif. Posisi perempuan selalu digambarkan sebagai sosok yang lemah, baik dalam pola berketubuhan maupun relasi dengan laki-laki (Ritonga, 2016).

Akan tetapi, tidak semua perempuan dalam novel dinilai secara stereotip. Setidaknya pada novel Eliana tersebut. Novel Eliana sudah beberapa kali dikaji dalam riset. Setiawan (2017) misalnya mengkaji "Penguatan Nilai Karakter Cinta Lingkungan Melalui Karakterisasi Tokoh Utama dalam Novel Eliana Karya Tere Liye". Pendidikan Karakter juga menjadi fokus Saputra (2020) ketika membahasa novel Eliana. Novel tersebut dalam tilikan Saputra (2020) memiliki relevansi dengan silabus dan rencana pembelajaran di Sekolah Menengah karena terdapat nilai pendidikan karakter seperti cinta damai, disiplin dan demokratis.

Novel karya Tere Liye itu juga pernah diteliti dalam paradigma strukturalisme genetik oleh Mustomi dan Munir (2018). Novel tersebut, dalam temuan mereka, mengandung unsur dan pesan moral-sosial yang bisa diajarkan kepada siswa. Sedangkan, dalam aras gender, novel Eliana, sebagaimana riset Agustia (2020) mengungkap nilai-nilai kemandirian tokoh Eliana. Terdapat kemandirian emosional, kemandirian perilaku dan kemadirian nilai yang dimiliki tokoh Eliana. Selain kemandirian, terdapat juga nilai pendidikan dalam novel tersebut, antara lain: pendidikan kecerdasan, pendidikan sopan santun, kesejahteraan dan sosial (Yenhariza \& Nirizzati, 2012).

Beberapa kajain di atas menunjukan bahwa isu gender dan nilai ke-Islaman belum dikaji secara komprehensif. Oleh sebab itu, posisi peneltiian ini adalah memberi tambahan perspektif gender dan nilai-nilai moral Islam yang terdapat pada novel Eliana karya Tere Liye.

\section{Novel sebagai Karya Sastra}

\section{Pengertian Novel}

Burhan Nurgiyantoro mengemukakan bahwa novel sebagai karya fiksi menawarkan sebuah dunia yang berisi model kehidupan yang diidealkan, dunia imajinatif yang dibangun melalui berbagai unsur intrinsiknya seperti peristiwa, 
plot, tokoh dan penokohan, latar, dan sudut pandang yang kesemuanya bersifat imajinatif, walaupun semua yang direalisisasikan pengarang sengaja dianalogikan dengan dunia nyata tampak seperti sungguh ada dan benar terjadi, hal ini terlihat sistem koherensinya sendiri (Yanti, 2015). Menurut Tarigan, kata novel berasal dari kata latin, novelius, yang pula diturunkan pada kata noveis yang berarti baru. dikatakan baru karena kalau dibandingkan dengan karya sastra yang lain seperti puisi, drama, dan lain-lain, maka jenis novel ini muncul kemudian (Tarigan, 2000).

Berangkat dari definisi di atas, novel bisa diartikan sebagai proyeksi dari pengarang terhadap realitas. Artinya faktor kesadaran dan pengalaman pengarang hadir dalam proses terciptanya peristiwa, plot, tokoh, dan penokohan, meskipun sifatnya imajinatif. Novel menjadi karya fiksi yang dapat dianggap sebagai miniatur kehidupan. Bisa saja cerita yang ditawarkan oleh pengarang berangkat dari peristiwa nyata, misalkan novel Trologi Ronggeng Dukuh Paruk karya Ahmad Tohari, tetralogi Pulau Buru (Bumi Manusia, Jejak Langkah, Anak Semua Bangsa, Rumah Kaca) milik maestro novel Indonesia, Pramoedya Ananta Toer, Dr. Zhivago garapan Boris Pasternak, hingga Tenggelamnya Kapal Van Der Wijck milik Hamka. Bahkan di antaranya sudah diangkat menjadi film layar lebar. Artinya, novel memberikan alternatif wacana dalam kehidupan kesenian dan kebudayaan pada masyarakat, sekaligus pendekatan untuk dapat memahami persoalan kemanusiaan.

Hal tersebut mengamini apa yang disampaikan oleh H.B. Jassin bahwa novel adalah suatu kejadian yang luar biasa dari kehidupan orang-orang luar biasa karena kejadian ini terlahir suatu konflik, suatu pertikaian, yang mengalihkan jurusan nasib mereka (Suroto, 1989).

\section{Unsur-unsur Novel}

Sebagai sebuah karya sastra, seperti halnya puisi dan cerita pendek, novel memiliki unsur-unsur yang dapat membangun sebuah cerita dan pemaknaan kapada pembaca. Unsur-unsur dalam novel dapat diidentifikasi sebagai berikut:

\section{Unsur Ekstrinsik}

Unsur ekstrinsik adalah unsur-unsur yang berada di luar karya sastra itu sendiri, tetapi secara tidak langsung mempengaruhi bangunan atau sistem organisme karya sastra (Yanti, 2015). Unsur-unsur ekstrinsik ini antara lain adalah keadaan subjektivitas individu pengarang yang mempunyai sikap, keyakinan, 
dan pandangan hidup yang semuanya akan mempengaruhi karya sastra yang ditulisnya. Unsur ekstrinsik sebuah karya sastra bergantung kepada pengarang yang menceritakan karya itu.

Wellek dan Warren mengemukakan bahwa unsur ekstrinsik karya sastra meliputi unsur biografi; unsur psikologis, keadaan lingkungan, dan paradigma/ perspektif seseorang. Sedangkan, unsur ekstrinsik novel adalah: pertama, latar belakang masalah, kedua, kondisi sosial budaya, ketiga, tempat novel dikarang (Wellek, Rene dan Warren, 2014)

Unsur esktrinsik akan mempengaruhi karakteristik novel yang ditulis oleh pengarang. Dalam Ronggeng Dukuh Paruk misalnya, Ahmad Tohari dengan piawai mengangakat tema kearifan lokal. Hal itu disebabkan Ahmad Tohari terlibat langsung dan dengan penuh kesadaran ia merekam dan mencatat semua gejala kemanusiaa yang terjadi di desanya, Jatilawang. Belum lagi dinamika politik yang sangat represif yang sedang berkecamuk dengan isu G $30 \mathrm{~S} / \mathrm{PKI}$, sehingga orang-orang desa tempat Ahmad Tohari tinggal merasakan imbasnya langsung. Selain itu, tokoh Zainuddin dan Hayati, dalam novel Tenggelamnya Kapal Van Der Wijk, karya Hamka juga merupakan proyeksi atas kisah cinta yang terhalang oleh perbedaan adat dan budaya. Hamka dengan brilian menempatkan Zainuddin dan Hayati sebagai simbol kultural, Mengkasar dan Minangkabau. Oleh sebab itu, bisa jadi unsur ekstrinsik sebuah karya sastra dapat dijadikan kritik atas dialektika kebudayaan yang jumud atau dominan.

\section{Unsur Intrinsik}

Unsur intrinsik adalah unsur-unsur yang membangun karya sastra itu sendiri. Unsur intrinsik sebuah novel, lazimnya sebuah unsur karya sastra lainnya, adalah sebagai berikut: tema, latar, amanat, alur, tokoh, sudut pandang, dan gaya bahasa.

\section{Tema}

Tema merupakan gagasan dasar yang menopang sebuah karya sastra (novel) dan yang terkandung di dalam teks sebagai struktur semantis dan yang menyangkut persamaan-persamaan atau perbedaan-perbedaan (Nurgiyantoro, 2010). Tema dalam sebuah novel sifatnya mengikat, karena tema akan menentukan peristiwa dan penokohan di dalam cerita. Tema berfungsi sebagai dasar pengembangan sebuah cerita dalam novel, sehingga pengarang musti menjiwai tema dan persoalan 
yang akan diceritakan, sehingga tokoh dan penokohan, serta konflik dapat disajikan dengan menarik.

\section{Latar}

Setiap karya sastra (novel) yang membentuk cerita selalu memiliki latar. Latar dalam novel tidak sepenuhnya sama dengan realitas. Novel merupakan rekaan yang diciptakan oleh pengarang untuk dinikmati pembaca. Meskipun demikian, latar yang ada dalam novel tetap memiliki relevansi dengan realitas yang sesungguhnya, karena pengarang menciptakan karyanya berangkat dari pengamatan dan pengalaman terhadap lingkungannya. Yang dimaksud dalam lingkungan ini adalah adat, kebudayaan, norma, hukum, dan dan alam semesta (Yanti, 2015).

Membaca sebuah novel, sama saja dengan berhadapan dengan dunia, baik itu dunia pemikiran pengarang, dunia cerita novel sendiri, ataupun dunia pemaknaan yang dilakukan oleh pembaca secara independen. Maka dari itu, latar akan selalu menentukan suasanan batin sebuah novel, dikarenakan latar akan selalu berhubungan dengan waktu, tempat, kondisi sosial, ekonomi, kebudayaan, agama, dan politik.

\section{Amanat}

Dalam beberapa litelatur amanat banyak disinggung dalam istilah moral. Moral seperti halnya tema, dilihat dari segi dikotomi bentuk isi karya sastra merupakan unsur isi. Ia merupakan sesuatu yang ingin disampaikan oleh pengarang kepada pembaca, merupakan makna yang terkandung dalam sebuah karya, makna yang disarankan lewat cerita (Nurgiyantoro, 2010).

Amanat dapat disampaikan oleh penulis melalui dua cara. Cara pertama, amanat disampaikan secara tersurat (ditulis secara langsung dalam sebuah karya sastra). Kedua, amanat disampaikan secara tersirat artinya pesan tidak dituliskan secara langsung di dalam teks melainkan disampaikan melalui unsur-unsur yang ada. Pembaca harapkan dapat menyimpulkan sendiri pesan atau amanat yang terkandung di dalam teks. Moral dalam karya sastra biasanya mencerminkan pandangan hidup pengarang yang bersangkutan, pandangannya tentang nilai-nilai kebenaran, dan hal itulah yang ingin disampikannya kepada pembaca. 


\section{Alur}

Alur merupakan terjemahan dari istilah Inggris plot. Alur adalah sambungsinambung peristiwa berdasarkan hukum sebab akibat. Alur tidak hanya mengemukakan apa yang terjadi, tetapi juga menjelaskan mengapa hal itu terjadi. Dengan sambung-sinambungnya peristiwa ini terjadilah sebuah cerita (Nuryatin, 2010).

Aminuddin berpendapat bahwa alur adalah rangkaian cerita yang dibentuk oleh tahapan-tahapan peristiwa sehingga menjalin suatu cerita yang dihadirkan oleh para pelaku dalam suatu cerita (Aminuddin, 1987). Alur cerita dapat dikategorikan ke dalam beberapa jenis yang berbeda berdasarkan kriteria urutan waktu, kepadatan (kualitatif) dan jumlah (kuantitatif). Berdasarkan urutan waktu, alur dapat dibedakan menjadi dua kategori, yaitu alur kronologis dan alur takkronologis. Alur kronologis disebut alur lurus atau alur maju atau alur progresif. Alur tak-kronologis disebut alur mundur, alur sorot balik, alur flash back atau alur regresif.

Alur maju adalah pengutaran peristiwa dari masa kini terus ke depan dengan gerak maju, sedangkan alur mundur adalah pengutaraan peristiwa dengan mengungkapkan masa lalu atau dengan tolehan kembali ke masa lalu. Dan dalam karya sastra tidak selalu salah satu alur saja yang dipakai pengarang, bukan hanya alur maju atau alur mundur semata-mata, melainkan dapat juga gabungan dari kedua alur tersebut. Hal inilah yang disebut alur gabungan.

\section{Sudut Pandang}

Sudut pandang atau point of view, secara umum diartikan sebagai dasar pemikiran dan pandangan dunia pengarang terhadap realitas. Sudut pandang akan berpengaruh terhadap tokoh, penokohan, alur, dan konflik di dalam novel, atau bahkan karya sastra yang lain. Pandangan dunia Emha Ainun Najib (Cak Nun) yang sufistik misalnya akan berimbas kepada objek pembahasan yang bersifat transendensi terhadap dinamika kehidupan manusia. Selain Cak Nun, Abdul Wachid B.S. (Achid) juga menjadi salah satu sastrawan yang memiliki sudut pandang unik. Beberapa kumpulan puisinya memiliki sudut pandang sosial-politik, agama, cinta, dan tasawuf sekaligus.

Dalam konteks novel, sejarah mencatat Armijn Pane melalui novel Belenggu, Eka Kurniawan dengan Cantik itu Luka, dan Pramoedya Ananta Toer mampu 
memberikan sudut pandang penceritaan yang mampu membangun intensi pembaca (mimesis) dengan situasi politik represif Orde Baru, penindasan terhadap perempuan, fundamentalisme agama, dan lain sebagainya. Oleh sebab itu, sudut pandang bisa dibagi menjadi beberapa jenis, yaitu sudut pandang orang pertama, orang kedua, dan orang ketiga.

\section{Gaya Bahasa}

Pada setiap karya sastra, baik prosa maupun puisi, dalam pemakaian bahasa antara pengarang yang satu dengan pengarang yang lain tidak sama. Dalam hal pemakaian bahasa ini terlihat adanya bermacam-macam gaya bahasa, yang memberikan corak yang bermacam-macam pula.

Dalam proses menulis pengarang akan senantiasa memilih kata-kata dan menyusunnya menjadi kalimat-kalimat sedemikian rupa sehingga mampu mewadahi apa yang dipikirkan dan dirasakan tokoh-tokoh ceritanya. Oleh karena itu dalam karya-karya sastra sering dijumpai pemakaian kata-kata dan kalimatkalimat khusus yang biasa dikenal dengan istilah pigura-pigura bahasa, dengan aneka jenisnya seperti metafora, metonimia, hiperbola, litotes, pleonasme, klimaks dan lain-lain.

Di lain pihak, tidak sedikit karya sastra yang tidak banyak menggunakan pigura-pigura bahasa tetapi lukisan-lukisan yang terkandung di dalamnya tetap hidup dan mengesankan, karena dalam hal ini yang penting ialah kemampuan pengarang dalam memilih kata-kata dan menyusunnya dalam kalimat-kalimat sehingga sanggup mengemban tugasnya dengan sempurna (Nuryatin, 2010).

\section{Sosiologi Sastra}

Dalam bukunya The Sociology of Literature, Swingewood sebagaimana dikutip oleh Faruk mendefiniskan sosiologi sebagai studi yang ilmiah dan objektif mengenai manusia dalam masyarakat, studi mengenai lembaga-lembaga dan proses-proses sosial. Selanjutnya dikatakan bahwa sosiologi berusaha menjawab pertanyaan mengenai bagaimana masyarakat dimungkinkan, bagaimana cara kerjanya, dan mengapa masyarakat bertahan hidup (Faruk, 2014).

Memaknai definisi Swingewood, sosiologi merupakan disiplin ilmu yang lokusnya adalah individu (manusia) dan institusi sosial (di dalamya termasuk juga 
regulasi, norma, hukum, dan adat yang membentuk). Idealnya adalah peradaban baru yang humanis. Sosiologi jelas akan selalu berkembang dan berkelindan dengan ilmu pengetahuan yang lain, sebab dari dinamika sosial-lah, fakta kebudayaan, agama, konflik, rekonsiliasi, dinamika penyusunan regulasi bisa dipahami dan didekonstruksi.

Dalam struktur masyarakat Minangkabau, setidaknya fenomena itu tergambar pada novel Tenggelamnya Kapal Van Der Wijck, karya Hamka, menjelaskan secara cukup gamblang personifikasi dan metafora dominasi kebudayaan Minangkabau dalam konteks pernikahan. Sekalipun syariat Islam tidak secara eksplisit menyinggung persoalan keseragaman budaya dan adat untuk laki-laki dan perempuan melangsungkan pernikahan, namun adat Minagkabau mengehendaki adanya perjodohan yang seragam dalam hal budaya, sehingga berimplikasi terhadap pandangan hidup, status sosial, bahasa, dan perekonomian.

Sebagai sebuah disiplin keilmuan, dengan adanya contoh dari novel Hamka di atas, maka antara sosiologi dan sastra memiliki hubungan yang erat. Dalam novel Dataran Tortilla karya John Steinbeck misalnya, potret sosial-ekonomi masyarakat proletariat Amerika mampu terwakili dengan komprehensif. Ahmad Tohari bahkan mengaku terinspirasi dengan novel John Steinbeck itu, setidaknya ketika ia sedang menulis kumpulan cerpen "Mata yang Enak Dipandang". Ahmad Tohari, sebagaimana John Steinbeck, dan beberapa novelis formalis Rusia seperti Leo Tolstoy, Dostoyevski, hingga Anton Chekov memang sarat dengan ideologi kaum proletariat yang tersisih secara sosial-ekonomi, khususnya imbas dari perang di negaranya.

Sapardi Djoko Damono, mengamini Rene Wellek dan Austin Warren megatakan bahwa ia menemukan setidaknya tiga jenis pendekatan yang berbeda dalam sosiologi sastra, yaitu pertama, sosiologi pengarang yang memasalahkan status sosial, kedua, ideologi sosial dan lain-lain yang menyangkut pengarang sebagai penghasil karya sastra, ketiga, sosiologi karya sastra yang memasalahkan karya sastra itu sendiri, dan keempat, sosiologi sastra yang memasalahkan pembaca dan pengaruh sosial karya sastra. Dari Ian Watt, Sapardi juga menemukan tiga macam pendekatan, pertama, konteks sosial pengarang, kedua, sastra sebagai cermin masyarakat, ketiga, fungsi sosial sastra (Faruk, 2014).

Dalam pengungkapan persoalan manusia itu, seorang pengarang secara langsung atau secara tidak langsung telah menuangkan persoalan sosial ke dalam 
karyanya. Hal ini dimungkinkan karena pengarang biasanya cenderung dipengaruhi oleh apa yang dirasakan, dilihat dan dialami dalam kehidupan sehari-hari. Sosiologi dan sastra sama-sama menguraikan masalah masyarakat. Dengan demikian sastra pada zaman modern ini dapat dianggap sebagai usaha untuk menciptakan kembali dunia sosial. Hubungan manusia dengan keluarganya, lingkungannya, adat istiadanya dan lain-lain.selanjutnya sosiologi sebagai ilmu yang akan mencoba mengungkapkan kembali problema sosial tersebut.

Di dalam teori sosiologi, sastra dan bahasa dipandang sebagai institusi sosial yang penting. Sebagai sesuatu yang terbagi secara kolektif, bahasa merupakan indikator dari keberadaan realitas seseorang yang terlepas dari individu. Dalam bahasalah dunia sosial dikukuhkan sekaligus dipelihara. Selain itu, bahasa juga menduduki posisi yang pentiing dalam mengukuhkan sifat objektif dari dunia sosial. Melalui bahasa pula dunia sosial yang objektif diinternalisasikan ke dalam kesadaran subjektif para warga dari dunia sosial tersebut (Berger, 1991).

\section{Nilai-Nilai Moral Islam dalam Novel Eliana}

Moral adalah tingkah laku perbuatan manusia yang dipandang dari nilai nilai baik dan buruk, benar dan salah, dan berdasarkan adat kebiasaan di mana individu tersebut hidup. Adapun nilai-nilai moral Islam dalam bahasa agama disebut dengan akhlaq yaitu nilai-nilai dan sifat-sifat yang tertanam dalam jiwa, yang dengan sorotan dan timbangannya seseorang dapat menilai perbuatannya baik atau buruk, untuk kemudian memilih untuk melakukan atau meninggalkannya (Ilyas, 2001).

Ruang lingkup akhlak terbagi menjadi akhlak pribadi, akhlak berkeluarga, akhlak bermasyarakat, dan akhlak beragama. Dari sistimatika tersebut Yunahar Ilyas membagi akhlak manusia menjadi akhlak terhadap Allah, akhlak terhadap Rasulullah, akhlak pribadi, akhlak dalam keluarga, akhlak bermasyarakat dan akhlak bernegara (Ilyas, 2001).

Nilai nilai moral Islam yang terkandung dalam novel Eliana: tauhid, kejujuran, disiplin, cinta kasih, kesabaran, kerukunan, keberanian, cinta alam, kerja sama, syukur, qana’ah, berbakti pada orang tua, memaafkan, keadilan, taubat, musyawarah, amar ma’ruf nahi munkar. 


\section{Tauhid}

Tauhid merupakan bagian utama dari akidah kepada Allah. Semua utusan Allah, membawa pesan-pesan akidah yakni tauhid, meng-Esa-kan Allah (Setiawan, 2017). Tauhid juga bersifat esoterik dan eksoterik (Syarif, 2014). Sebagai misi utama nabi dan rasul, tauhid diposisikan sebagai objek dakwah kepada umat manusia. Bila ditinjau secara lafadz, kata "tauhid" tidak ditemukan dalam al-Qur'an, tetapi, terdapat pada Hadits nabi dalam bentuk kata kerja dan masdar. Nabi Saw bersabda: "Sesungguhnya engkau Mu’adz, akan mendatangi kaum Ahlul Kitab, maka hendaklah dakwahmu yang pertama kali kepada mereka adalah mentauhidkan Allah" (Al-Daraqutni, 2004).

Penanaman nilai-nilai tauhid ditanamkan melalui pembahasan tentang adanya selebaran yang beredar dengan judul Berita Penting bagi Ummat Islam seluruh Dunia, di mana isinya memerintahkan pada yang menerimanya untuk melakukan hal-hal yang disebutkan dalam selebaran tersebut. Barang siapa yang mentaatinya maka selamat sedangkan yang mengabaikannya akan celaka, selanjutnya supaya menyalin 20 kali lalu membagikan ulang supaya terhindar dari marabahaya. Tak kurang dari Pak Guru, Bapak, dan Nek Kiba menjelaskan tentang bahaya syirik dan hendaknya hanya meminta pertolongan dan menggantungkan harapan pada Allah semata. Kejadian lainnya adalah ketika Bapak membawa dua buah batu kali yang indah, Pukat bertanya apakah benar batu tersebut memiliki khasiat bisa menyembuhkan segala macam penyakit. Bapak menjawab bahwa menatap batu yang indah hati menjadi senang dan hati yang senang bisa menjadi sumber kesehatan. (hal. 17)

\section{Kejujuran}

Penanaman nilai kejujuran diceritakan dalam bab 19 yang berjudul "Jahil" di mana Eliana kehilangan bando hadiah dari Wak Yati yang dibeli di kota propinsi sehingga bando tersebut menjadi benda yang berharga baginya. Beberapa hari Eliana mencari bando tersebut ke semua sudut rumah, bertanya bahkan menggeledah kamar kepada adik-adiknya, menuduh mereka bersekongkol menyembunyikannya, namun bando itu tak kunjung ditemukan. Sampai suatu saat Mamak memintanya untuk mengambil kunyit di halaman. Saat ia mengarahkan cangkulnya untuk mengambil kunyit, cangkulnya mengenai benda keras yang ditanam di dekat rumpun kunyit, dan ketika ia menggalinya lebih dalam ia menemukan bando yang 
selama ini dicarinya ke mana-mana dalam keadaan sudah patah. Dan pada saat makan malam ia menginterograsi ketiga adiknya siapa yang mematahkan bando lalu menguburnya di halaman.

\section{Kesabaran}

Sabar merupakan serapan dari bahasa Arab, yaitu shabr, yang terdiri dari huruf shad, $b a$ ', $r a$ '. Kata shabr merupakan bentuk mashdar (pembendaan) dari kata shabara. Dari sisi leksikal, kata shabara memiliki beragam arti. Jika diikuti partikel 'ala, bermakna sabar atau tabah hati. Bila diikuti pertikel 'an berarti amsaka (menahan atau mencegah). Sedangkan, bila diikuti partikel $h u$ berarti akraha wa alzama (memaksa dan mewajibkan) (Hadi, 2018). Sementara itu, menurut Quraish Shihab, sabar artinya menahan diri atau membatasai jiwa dari keinginan demi mencapai sesuatu yang baik atau luhur (Shihab, 2007).

Nilai-nilai kesabaran diilustrasikan dalam peristiwa ketika Pukat dan Burlian diminta untuk membantu Mamak menumbuk biji kopi. Mereka berdua merasa pekerjaan ini terlalu berat dan lama. Namun Mamak tetap bersikeras menyuruh mereka untuk menyelesaikan pekerjaan mereka. Bahwa menumbuk biji kopi memerlukan waktu, tidak bisa seketika biji kopi menjadi halus melainkan harus tetap ditumbuk sehingga lama kelamaan biji kopi akan hancur dan menjadi lembut.

\section{Cinta kasih}

Nilai-nilai cinta kasih diajarkan oleh Bapak dan Mamak melalui contoh kehidupan sehari-hari. Terutama Eliana sebagai anak sulung harus menunjukkan kasih saying kepada adik-adiknya melalui perhatian seperti memastikan adikadiknya sudah bangun pagi, sudah mandi, sudah makan sebelum berangkat ke sekolah. Juga memastikan adik-adiknya sudah pulang, berangkat mengaji, mengerjakan PR dan pergi tidur.

\section{Menepati Janji}

Pada jam pelajaran olahraga di sekolah terjadi persaingan antara anak lakilaki dan perempuan. Anton meremehkan anak perempuan bahwa mereka tidak mungkin bisa menang lomba lari dengan memakai rok dan berambut Panjang. Eliana tidak terima diremehkan, ia menantang Anton untuk lomba lari mengelilingi 
lapangan sepuluh kali. Mereka mengadakan perjanjian jika Eliana kalah ia akan berteriak lantang mengatakan bahwa anak perempuan tidak bisa mengalahkan anak laki-laki dalam hal apapun. Sedangkan jika Anton kalah ia dan anak laki-laki lainnya akan memakai rok ke sekolah. Maka lomba laripun dimulai yang akhirnya dimenangkan oleh Eliana. Oleh karena itu besoknya Anton dan anak laki-laki kelas enam menepati janjinya berangkat ke sekolah memakai rok.

\section{Kerukunan}

Kerukunan adalah sebuah nilai moral yang dikembangkan dalam berinteraksi dengan orang lain, baik itu saudara maupun teman. Nilai-nilai kerukunan digambarkan dalam beberapa scene baik itu di sekolah maupun di rumah. Di sekolah diantaranya saat bermain bersama pada jam istirahat, di rumah saat menggunakan fasilitas bersama, berbagi kamar, makanan, menemani bermain, pergi dan pulang mengaji bersama.

\section{Keberanian}

Eliana, Hima, Damdas dan Marhotap membentuk gang Empat Buntal yang tugasnya adalah mengamati truk truk penambang pasir di sungai kampung. Penambangan pasir yang dilakukan telah menyebabkan kerugian bagi penduduk kampung, yaitu mengecilnya aliran iar sungai, keruhnya air yang digunakan untuk mencuci oleh penduduk, berkurangnya ikan di sungai. Oleh karena itu penambangan pasir harus segera dihentikan sebelum menimbulkan kerugian dan kerusakan alam lebih banyak. Gang Empat Buntal melakukan beberapa tindakan seperti menyebarkan paku di jalan sehingga truk-truk tersebut tidak bisa beroperasi. Mereka adalah para pemberani yang melakukan aksi untuk kepentingan kampungnya.

\section{Qana'ah}

Qana’ah dari segi bahasa artinya menerima apa adanya atau tidak serakah (Abdusshomad, 2020). Sementara, secara istilah qana’ah merupakan satu akhlak mulia yaitu menerima rezeki apa adanya dan menganggapnya suatu kekayaan yang menghindarkan dirinya dari sifat meminta-minta (Hajjad, 2011). Qana'ah menumbuhkan sikap bersyukur dan erat kaitannya dengan konsep zuhud. Sebab, 
dunia berada di tangannya, bukan di hatinya.

Dalam novel Eliana, sifat qana’ah ditunjukan Keluarga Pak Syahdan. Mereka keluarga sederhana. Untuk keperluan sekolah anak-anak mereka harus bergiliran untuk mendapatkan baju seragam baru. Tahun ini giliran Amelia untuk membeli seragam baru. Namun Amelia juga menginginkan tas sekolah baru. Kebetulan Babah Lim memberi lungsuran seragam kepada Amelia sehingga uang yang harusnya untuk membeli baju seragam bisa diperuntukkan membeli tas sekolah Amelia. Anak-anak bisa menerima keadaan ini dengan baik, karena jika dibandingkan dengan tetangga mereka, banyak yang anaknya tidak sekolah, bahkan untuk makan saja mereka sulit.

\section{Memaafkan}

Suatu malam Bapak pulang dari rapat dengan tetua kampung dengan membawa dua buah batu kali yang sangat indah, diberi oleh ayah Marhotap sebagai hadiah karena Bapak mengenalkan ayah Marhotap kepada Babah Lim pemilik toko perhiasan di kota. Batu tersebut diberikan kepada Amelia dan Eliana. Suatu hari Marhotap membawa batu kali yang indah dan memamerkannya ke anak-anak di sekolah. Pada jam istirahat dia kehilangan batu tersebut dan meminta supaya seluruh tas teman-temannya digeledah. Dia menemukan batu yang sama persis di tas Eliana lalu menuduhnya mencuri batu miliknya.

\section{Birrul walidain}

Sebagai anak perempuan pertama di keluarganya Eliana mempunyai tugas yang berbeda dibandingkan dengan ketiga adiknya. Mamak memberi Eliana tanggungjawab yang terkait dengan adik-adiknya. Misalnya apakah Pukat sudah bangun, apakah Burlian sudah mandi, apakah Amelia sudah sarapan. Jika adikadiknya belum siap maka Mamak akan menegur Eliana. Demikian pula jika adikadiknya bertengkar Mamak juga menegur Eliana. Hal ini membuat Eliana merasa bahwa Mamak tidak menyayanginya sebagaimana terhadap adik-adiknya. Mamak selalu memarahinya bahkan saat ia tidak melakukan kesalahan. Dan puncaknya saat Eliana diberi tanggung jawab untuk mengantarkan Burlian dan Pukat menonton film layer tancap di lapangan kota kecamatan. Awalnya semua berjalan baik, sama Eliana bertemu dengan Hima dan Damdas teman sekelasnya, sehingga ia asyik menonton Bersama mereka. Saat film telah selesai ia tidak menemukan 
Pukat dan Burlian diantara penonoton. Ia sudah mencari sampai semua penonton pulang, namun keduanya tak Nampak. Akhirnya ia pulang dan mendapati Pukat dan Burlian sudah di rumah. Awalnya Eli hendak marah kepada keduanya, namun ia melihat kaki Pukat diperban dan ia terbaring diatas tempat tidur. Barulah ia sadar kalua Pukat kakinya terluka dan pulang lebih awal. Ia melihat Mamak sibuk merawat Pukat, tidak mengucapkan sepatah katapun terhadapnya. Eliana merasa semua orang terutama Mamak menyalahkan dirinya. Karena itu ia lari keluar rumah menuju rumah Wak Yati, bibinya. Eliana tinggal di rumah Wak Yati selama beberapa hari, dan selama itu keyakinannya bahwa Mamak tidak menyayanginya semakin menguat. Hal ini karena Mamak tidak pernah menanyakannya, bahkan Mamak sendiri yang mengantar seragam sekolah dan keperluan lainnya ke rumah Wak Yati sehingga Eliana merasa Mamak telah mengusirnya dari rumah.

\section{Bersungguh-sungguh}

Eliana selama ini menjadi anak yang selalu dapat diandalkan dan dipercaya oleh Pak Bin untuk membantu melakukan tugas-tugas di sekolah seperti memukul bel, membawakan buku, mengambil presensi kelas, mengumpulkan PR. Sebaiknya Marhotap adalah anak yang dikenal malas, selalu terlambat, jarang mandi, tidak pernah tepat menyelesaikan PRnya, mendapat peringkat buruk di kelas. Namun akhir-akhir ini Marhotap berubah menjadi anak yang rajin, mengerjakan PR dengan baik, bahkan bisa menjawab soal-soal yang diberikan oleh Pak Bin. Marhotap berubah sejak ia melihat kesulitan hidup yang dialami keluarganya karena hidup tidak berpendidikan dan dalam kemiskinan. Sejak itu dia semakin rajin membawa ayahnya dalam bekerja mecari batu alami di sungai, dan bersungguh-sungguh belajar di rumah Pak Bin setiap sore hari.

\section{Nilai-Nilai Kesetaraan Gender dalam Novel Eliana}

Secara historis telah terjadi dominasi laki-laki dalam semua masyarakat di sepanjang zaman. Perempuan dianggap lebih rendah dari laki-laki. Dari sini muncullah doktrin ketidaksetaraan antara laki-laki dan perempuan (Engineer, 1994), yang kemudian menimbulkan berbagai ketidakadilan gender. Mansur Fakih menyebutkan beberapa bentuk ketidakadilan gender yaitu stereotip, subordinasi, marjinalisasi, beban ganda dan kekerasan (Fakih, 2004).

Ketidakadilan gender sebagaimana tersebut di atas banyak terjadi di 
masyarakat dan merupakan keadaan yang secara sosial, kultural dan budaya dibentuk sedemikian rupa sehingga seolah-olah menjadi sesuatu yang dianggap natural (Susilaningsih \& Najib, 2001). Untuk itu diperlukan sosialisasi dan gerakan untuk mengkampanyekan penghapusan ketidakadilan gender dan membangun relasi kesetaraan gender di masyarakat.

Kesetaraan gender adalah persamaan hak sebagai manusia sebagai makhluk ciptaan Allah yang memiliki kemampuan untuk saling melengkapi sebagaimana disebutkan dalam ayat-ayat Al-Qur'an yang menekankan kesetaraan kedudukan bagi laki-laki dan perempuan, di antaranya dalam QS. 4:1, 33:35, 49:13.

Untuk melihat nilai-nilai kesetaraan gender dalam novel Eliana maka perlu ditinjau dari tiga hal yaitu bagaimana pandangan tokoh laki-laki terhadap perempuan, bagaimana peran laki-laki dan perempuan digambarkan dalam novel ini dan bagaimana citra tokoh laki-laki dan perempuan.

Pandangan tokoh laki laki dan perempuan: sebagian tokoh laki laki pada novel Eliana memandang perempuan sebagai sosok yang lemah, cengeng, mudah dikalahkan oleh laki laki (Anton, Damdas, Marhotap). Sebagaimana terdapat pada halaman 291:

"Mana ada anak perempan yang bisa mengalahkan kami lari," demikian kata Anton jumawa, mencibirkan mulutnya pada anak-anak perempuan.

"Oi, lihat, lihat, pakai rok begini mau lari. Belum lagi rambut panjangnya goyang sana, goyang sini. Keberatan di rambut, mana bisa mengalahkan kami." Anton tidak mau kalah berseru menyebalkan. Diikuti seruan murid laki-laki lain, mengangguk-angguk setuju."

Sementara anak perempuan memandang anak laki-laki sebagai sosok yang mengandalkan kekuatan fisik semata jika dikalahkan oleh perempuan. Sebagaimana disebutkan dalam hal 292: "Sebal dikalahkan oleh perempuan, ditertawakan pula aat sevisnya menyangkut net, Anton tidak sengaja memukul bola melewati bawah net, bola mental mengenai wajah salah satu teman perempuan"(hal 292). Sedangkan tokoh laki-laki yang lebih dewasa memandang perempuan sebagai sosok yang bisa memiliki kemampuan yang setara dengan laki laki (Bapak, Pak Bin, Paman Unus).

Citra tokoh laki laki dan perempuan: tokoh utama dalam novel ini adalah Eliana seorang anak perempuan berusia 12 tahun yang memiliki sifat yang berbeda dari anak-anak perempuan lainnya. Eliana dikenal sebagai anak pemberani, pintar, tidak mau kalah dengan anak laki-laki dalam berbagai bidang baik itu akademik 
(pelajaran) maupun non akademik (lomba lari, melakukan adzan di mushola) laki laki dicitrakan sebagai sosok yang kuat, keras, sementara perempuan sebagai lemah lembut, cantik, cengeng. Sosok Eliana sendiri dicitrakan berbeda dengan perempuan lainnya di mana Bapak selalu menyebut Eliana sebagai putri sulungnya yang pemberani.

Secara umum konstruk social yang berlaku dalam masyarakat ketika mencitrakan sosok laki-laki dan perempuan adalah sebagai berikut, laki-laki merupakan makhluk gagah, kuat, perkasa, tegas, pemberani, pekerja keras, bertubuh tegap, cepat mengambil keputusan dan tidak emosional. Sementara perempuan adalah sebaliknya dicitrakan sebagai sosok yang cantik, lembut, lemah, cengeng, penakut, lamban, berpikir lambat, dan emosional. Padahal sifat-sifat yang dicitrakan pada laki-laki maupun perempuan di sini adalah sifat-sifat yang bisa dipertukarkan. Artinya sangat mungkin didapati sosok laki-laki yang lemah, penakut, cengeng dan lamban. Sebaliknya ada pula perempuan yang bersifat keras, tegas, pekerja keras, cepat mengampil keputusan, pemberani dan kuat.

Dalam novel ini pengarang mencitrakan Eliana sebagai sosok yang berbeda dari perempuan sebagaimana yang dikonstruk masyarakat. Ini menunjukkan bahwa sifat-sifat perempuan dan laki-laki bisa dipertukarkan kecuali sifat-sifat kodrati seperti perempuan melahirkan, menyusui, menstruasi yang tidak bisa digantikan oleh laki-laki.

Peran tokoh laki laki dan perempuan: peran gender terbagi dalam peran domestik dan peran publik. tokoh emak, Wak Yati, Eliana, Amelia digambarkan sebagai perempuan yang memiliki peran domestik sepenuhnya. Hal ini terlihat dari aktifitas yang dilakukan dalam keluarga pada malam hari.

"Mamak sedang menganyam keranjang di ruang depan. Bapak sedang membaca buku. Amelia sedang tiduran menggambar sesuatu. (hal.274)

Mamak meletakkan anyaman,"Anak perempuan itu harus tangkas Eli. Tangnnya juga harus serajin mulutnya. Habis makan sendok-sendok dicuci. Habis menggunakan ssuatu, segera simpan dan bereskan. Menemukan smpah atau sesuatu yang tidak beres, rapikan. Ini malah sebaliknya. Berserakan, malas, ditunda-tunda. Pantas saja bando kuning kau hilang. Juga benda-benda lain.....Amel, kau juga dengar, hah? Nasehat Mamak ini juga buat kau." (hal. 276) 
Keluarga Pak Syahdan mempunyai empat orang anak, dua perempuan dan dua laki-laki. Namun Mamak hanya menyuruh Eliana sebagai anak perempuan untuk melakukan hal-hal yang terkait dengan urursan rumah tangga seperti mencuci perabotan setelah makan, membereskan benda-benda di rumah. Sementara anak laki-laki dibebaskan. Hal ini karena masih ada anggapan bahwa pekerjaan rumah tangga merupakan kewajiban kaum perempuan saja.

Namun meskipun demikian kaum perempuan memiliki hak bersuara dan mengambil keputusan baik dalam keluarga maupun masyarakat. Wak Yati digambarkan sebagai perempuan yang berpengetahuan luas, bisa berbahasa asing (Belanda), dan pernah bepergian jauh ke luar daerah sampai ke Malaka pada masa mudanya. Mamak sebagai seorang istri dan ibu sangat dihormati oleh seluruh anggota keluarga dan pendapatnya atau keputusannya tentang suatu hal dipatuhi oleh Bapak dan anak anak. Sedangkan tokoh Eliana diceritakan sebelas tahun kemudian menjadi pengacara terkenal setelah menempuh pendidikan SMP di kota kabupaten, SMA di kota propinsi dan kuliah di universitas terbaik di negeri ini dengan beasiswa yang diperolehnya.

Secara umum peran gender dibedakan dalam dua wilayah yaitu peran public dan peran domestik. Peran public adalah peran seseorang yang beraktifitas di wilayah terbuka atau luas di mana aktifitasnya mendapat bayaran, seperti bekerja menjadi karyawan kantor, guru, dokter, hakim, pengacara, pedagang, maupun pekerjaan-pekerjaan lainnya. Sedangkan peran domestic adalah pekerjaan yang dilakukan oleh seseorang dalam lingkup terbatas yaitu rumah atau keluarga dan tidak mendapat bayaran seperti pekerjaan mencuci, memasak, membersihkan rumah, mengasuh anak. Peran public biasanya dilakukan oleh kaum laki-laki sedangkan peran domestic dilakukan oleh kaum perempuan.

Dalam novel Eliana penulis bermaksud menggambarkan keseimbangan peran baik domestik maupun publik bagi tokoh perempuan yang ada dalam novel ini yang diwakili oleh Eliana, Mamak dan Wak Yati. Terutama sosok Eliana di mana ia tetap terampil melakukan pekerjaan rumah tangga sebagai hasil didikan Mamak sejak kecil dan tetap berprestasi secara akademik dan berkarir bagus sebagai seorang penggacara terkenal ketika dewasa.

Dalam menilai apakah sebuah tatanan masyarakat yang tergambar dalam novel Eliana ini mengandung nilai-nilai kesetaraan gender dapat diukur melalui bagaimana eksistensi tokoh perempuannya. Yaitu eksistensi dalam pendidikan, eksistensi dalam pekerjaan dan eksistensi secara sosial. Yaitu apakah kaum 
perempuan sudah mendapatkan akses dan manfaat yang sama dengan laki-laki dalam tiga hal di atas, yaitu pendidikan, pekerjaan dan social kemasyarakatan.

Anak laki laki dan perempuan secara kodrati memiliki perbedaan bentuk secara fisik, misalnya laki laki memilik alat kelamin berupa penis, memiliki jakun, dan menghasilkan sperma sedangkan perempuan memiliki alat kelamin berupa vagina, memiliki rahim, menghasilkan sel telur, bisa hamil dan menyusui. namun untuk hal hal selain perbedaan fisik sifat laki laki dan perempuan adalah sama seperti kemampuan di bidang akademik, kemampuan psikomotorik, kemampuan afektif. Tinggi rendahnya kemampuan tersebut baik laki laki maupun perempuan tergantung pada pendidikan, pelatihan dan pembiasaan yang mereka terima. Sebagai contoh, seorang anak perempuan yang sejak kecil dilatih untuk bersikap lemah lembut maka ia akan membawa sikap tersebut sampai dewasa. Namun jika ia sejak kecil dididik menjadi anak yang tegas dan pemberani, maka sikap tegas dan pemberani tersebut yang akan ia bawa sampai dewasa. Sebaliknya seorang anak laki laki jika sejak kecil dididik manja dan lemah maka di saat dewasa akan menjadi laki laki yang lemah dan tidak mandiri.

\section{Simpulan}

Kajian terhadap nilai-nilai moral Islam yang terdapat dalam novel Eliana ini diantaranya adalah tauhid, kejujuran, keberanian, kerja sama, qana’ah, disiplin, cinta kasih, birrul walidain, tanggung jawab, menepati janji, kerukunan, cinta alam, memaafkan dan bersungguh-sungguh. Nilai-nilai tersebut disisipkan dalam alur cerita sehingga mudah dipahami dan tidak terkesan menggurui.

Nilai kesetaraan gender dalam novel Eliana dilihat dari tiga hal yaitu pandangan tokoh laki-laki terhadap perempuan dan sebaliknya, citra tokoh lakilaki dan perempuan, serta peran tokoh laki-laki dan perempuan. Tokoh laki-laki dewasa memandang perempuan sebagai sosok yang bisa diandalkan, memiliki kemauan kuat untuk maju dan pemberani. Sementara tokoh laki-laki yang masih dalam katagori anak-anak memandang perempuan sebagai sosok yang lemah, cengeng dan tidak bisa mengalahkan laki-laki. Sedangkan citra perempuan dalam novel ini adalah menggambarkan sosok perempuan yang berbeda dari yang selama ini diyakini oleh masyarakat sebagai yang lemah lembut, cengeng, penakut dan lamban. Sebaliknya tokoh utama dari novel ini justru bersifat pemberani, cerdas, cekatan, tegas dan tidak cengeng. 
Adapun peran gender dalam novel Eliana ditampilkan secara seimbang, baik peran domestik maupun publik. Terutama bagi tokoh utama perempuan yang ada dalam novel ini yaitu Eliana di mana ia tetap terampil melakukan pekerjaan rumah tangga sebagai hasil didikan Mamak sejak kecil namun tetap berprestasi secara akademik dan berkarir bagus sebagai seorang penggacara terkenal ketika dewasa.

\section{Daftar Pustaka}

Abdusshomad, A. (2020). Penerapan Sifat Qanảah Dalam Mengendalikan Hawa Nafsu Duniawi”. Jurnal Asy-Syukriyyah, 21(1). https://doi.org/10.36769/asy. v21i1.95.

Agustia, H. (2020). Nilai Kemandirian Tokoh Eliana Pada Novel Si Anak Pemberani Karya Tere Liye". Jurnal Penelitian, Pendidikan Dan Pembelajaran, 15(23), $1-19$.

Al-Daraqutni, I. A. al-H. M. bin al-H. (2004). Sunan al-Daraqutni: Kitab al-Zakah, Bab: a;-Hatsu 'ala Ikhraj al-Sadaqah wa Bayanu Qismatiha. Mu'ssasah AlRisalah.

Al-Jaziri, A. B. J. tt M. al-M. (n.d.). Madinah al-Munawwarah: Maktabah al-'Ulum wa al-Hukm.

Aminuddin. (1987). Pengantar Apresiasi Karya Sastra. Sinar Baru Algensindo.

Barker, C. (2000). Cultural Studies: Theory and Practice. Sage.

Berger, P. L. da. T. L. (1991). Langit Suci. LP3ES.

Engineer, A. A. (1994). Hak-Hak Perempuan dalam Islam.Yogyakarta: Yayasan Bentang Budaya.

Fakih, M. (2004). Analisis Gender dan Transformasi Sosial. Pustaka Pelajar.

Faruk. (2014). Pengantar Sosiologi Sastra Dari Strukturalisme Genetik sampai Postmodernisme,. Pustaka Pelajar.

Hadi, S. (2018). Konsep Sabar dalam Al-Qur'an”. Jurnal Madani, 1(2), 473-488.

Hajjad, M. F. (2011). Tasawuf Islam dan Akhlak (T. K. A. I. Fakhrin Ghozali (Trans.)). Amzah.

Ilyas, Y. (2001). Kuliah Akhlaq. LPPI.

Intan, T. (2020). Stereotip Gender Dalam Novel Malik dan Elsa karya Boy Candra”. Jurnal Bindo Sastra, 4(2), 85-94. https://doi.org/10.32502/jbs.v4i2.2401. 
Juditha, C. (2015). Gender dan Seksualitas dalam Konstruksi Media Massa”. Jurnal Simbolika, 1(1). https://doi.org/10.31289/simbollika.vli1.45

Mufidah, C., Basri, H., \& Sholihah, I. 'i. (2021). Analisi Gender Dalam Novel “Aku Lupa Bahwa Aku Perempuan” Perspektif Emansipasi Perempuan Qasim Amin". Gender Equality: International Journal of Child and Gender Studies, $7(1), 58-69$.

Mustomi, T., \& Munir, S. (2018). Kajian Strukturalisme Genetik Dalam Novel Eliana Karya Tere Liye". Literasi: Jurnal Penelitian Bahasa Dan Sastra Indonesia Serta Pembelajarannya, 2(1), 56-63. https://doi.org/10.25157/literasi.v2i1.1227.

Muzzakka, M. (2017). Perjuangan Kesetaraan Gender dalam Karya Sastra Kajian terhadap Novel Perempuan Berkalung Sorban dan Gadis Pantai”. Jurnal Nusa, 12(3). https://doi.org/10.30872/jbssb.v2i2.1046

Nurgiyantoro, B. (2010). Teori Pengkajian Fiksi. Gadjah Mada University Press.

Nuryatin, A. (2010). Mengabadikan Pengalaman dalam Cerpen. Rosda Karya.

Pratiwi, S. (2013). Pendidikan Karakter Berbasis Moral dalam Novel Eliana Karya Tere Liye dan Pembelajarannya di Kelas XII SMK”. Laporan Penelitian. Universitas Muhammadiyah Purworejo.

Ritonga, D. S. (2016). Kajian Gender Pada Novel Karya Nawal El Saadawi dan Sutan Takdir Alisjahbana”. Arabiyat: Jurnal Pendidikan Bahasa Arab Dan Kebahasaaraban, 3(1), 13-31.

Saputra, N. (2020). Nilai Pendidikan Karakter Dalam Novel Eliana Karya Tere Liye Dan Relevansinya Sebagai Bahan Ajar Sastra Di SMA”. Lingua Rima: Jurnal Pendidikan Bahasa Dan Sastra Indonesia, 9(1), 77-89. https://doi. org/10.31000/lgrm.v9i1.2402.

Saputro, B. (2017). Kesetaraan Gender Dalam Novel Gadis Pantai Karya Pramodeya Ananta Toer (Analisis Wacana Menggunakan Metode Sarah Mills)". In Laporan Peneltian. Institut Agama Islam Negeri (IAIN. Fakultas Dakwah.

Setiawan, A. (2017). Konsep Pendidikan Tauhid Dalam Keluarga Perspektif Pendidikan Islam". Jurnal Educasia, 2(1).

Shihab, Q. (2007). Secercah Cahaya Ilahi. Mizan.

Sumarjo, J. (2004). Catatan Kecil Tentang Menulis Cerpen. Pustaka Pelajar.

Suroto. (1989). Teori dan Bimbingan Apresiasi Sastra Indonesia untuk SMTA. Erlangga. 
Susilaningsih, \& Najib, A. M. (2001). Kesetaraan Gender di Perguruan Tinggi Islam. Yogyakarta: UIN Sunan Kalijaga dan Mcgill.

Syarif, Z. (2014). Pendidikan Profetik dalam Membentuk Bangsa Religius". Jurnal Tadris, 9(1).

Tarigan, H. G. (2000). Prinsip-prinsip Dasar Sastra. Angkasa.

Tim Penyusun. (1995). Kamus Besar Bahasa Indonesia. Balai Pustaka.

Wahab, H. J. (2020). Nilai Moralitas Kepemimpinan Pendidikan Islam": Vol. IX (Issue 1). https://doi.org/10.18860/ua.v0i0.2373

Wellek, Rene dan Warren, A. (2014). Teori Kesusastraan. Gramedia.

Yanti, C. S. (2015). Religiositas Islam dalam Novel Ratu yangg Bersujud Karya Amrizal Mochamad Mahdafi'. Jurnal Humanika, 3(15).

Yenhariza, D., \& Nirizzati, R. E. (2012). Nilai-Nilai Pendidikan Dalam Novel Eliana Karya Tere Liye". Jurnal Pendidikan Bahasa Dan Sastra Indonesia, 1(1), 167174. 
